Journal of Social Sciences 5(3): 188-192, 2009

ISSN 1549-3652

(C) 2009 Science Publications

\title{
A Review of the Determinants of Share Prices
}

\author{
${ }^{1}$ Tafirenyika Sunde and ${ }^{2}$ Abel Sanderson \\ ${ }^{1}$ Department of Economics, Polytechnic of Namibia, \\ School of Business and Management, P Bag 13388, Windhoek, Namibia \\ ${ }^{2}$ Midlands State University, Zimbabwe
}

\begin{abstract}
Problem statement: The main purpose of the review was to qualitatively establish the determinants of share prices in Zimbabwe. The review was carried out in 2006 before the situation in Zimbabwe deteriorated to the level where it is at the moment. Approach: To gather the information that we wanted we used interviews and the archival method. We targeted the people in the various organizations/companies that are registered on the Zimbabwe Stock Exchange (ZSE), stock exchange staff, stock broking firms, investment analysts and chief executives. Results: We concluded that there are economic, political and social factors that determine stock prices in Zimbabwe. However, economic and political factors were established to be the dominant factors in the determination of stock prices. Conclusion: We concluded that if the stock exchange is to perform well the economic and political situation in the country has to be stable. In other words government has to take some deliberate steps to ensure that the economy of the country is well run and also that there is political stability.
\end{abstract}

Key words: Stock market, economic factors, political factors, stability.

\section{INTRODUCTION}

The stock exchange has been perceived by many as the backbone for most contemporary economies, serving a critical need of raising capital funds for companies at a reasonably low cost as compared to other sources of finance such as borrowing. The stock exchange serves two critical functions; it provides a critical link between companies that need funds to set up new businesses or to expand their current operations and investors that have excess funds to invest in such companies and it provides a regulated market place for buying and selling of shares at prices determined by supply and demand, not withstanding other macroeconomic fundamentals such as interest and inflation rates. To meet their short-term cash requirements corporations usually borrow from banks. However, when corporations need long term financing they may sell their ownership interests in the company to the public, or borrow from the public by selling bonds. Stocks exist to enable companies in need of long term financing to sell pieces of their business as stock (equity securities) in exchange for cash. This is the principal method for raising capital other than issuing bonds. These publicly held shares could be traded to other investors on the stock market. The Zimbabwe Stock Exchange (ZSE) has become very important as an investment vehicle for both local and international investors especially after the introduction Economic Structural Adjustment Program (ESAP) in 1991 when borrowing rates increased to levels above one hundred percent. This study will try to unravel the major qualitative arguments of stock prices on the ZSE.

Origins of the Zimbabwe stock exchange: According to Zimbabwe Stock Exchange (ZSE), the first Stock Exchange in Zimbabwe was opened in 1896 in Bulawayo. It only operated for six years before it closed. The present ZSE was also founded in Bulawayo in 1946. In December 1951, a second floor was opened in Harare. In January 1974 the Zimbabwe Stock Exchange Act was promulgated which formalized the establishment of the present ZSE with its head office in Harare. A revised ZSE Act was published in 1996 as Chapter $24.18^{[8]}$.

The study also attempts to investigate the factors to be considered by one who wants to invest on the stock market. It has to be realized that there are many arguments that determine the share price or the general performance of the stock market: And these could be

Corresponding Author: Tafirenyika Sunde, Department of Economics, Polytechnic of Namibia, School of Business and Management, P Bag 13388, Windhoek, Namibia Tel: +264-61-2072406 Fax: +264-61-207 2442 
social, economic or political. This study, therefore, wants to identify all these factors so that future investors are guided as far as investment on the stock market is concerned.

Why companies go public?: According to Kelly ${ }^{[2,9]}$ a company is likely to seek a listing on the stock exchange for all or some of the following reasons:

- to raise further capital

- to enable the company's owners to liquidate a portion of their investment

- to enable public trading in the shares of the company to take place

- to facilitate the establishment and operation of a staff share option scheme

- to gain the prestige associated with a stock exchange listing as perceived by investors, customers, suppliers and employees

Once a company has been listed on the stock exchange it does not necessarily mean that it will permanently remain on the stock exchange. The stock exchange has the right to suspend trading in the shares of any listed company at any time for the following reasons:

- a company may no longer satisfy the minimum requirements for listing, for example it may have become technically insolvent

- a listed company may have failed to comply with requests by the stock exchange to conform to certain requirements

- a listed company or companies may become involved in merger, acquisition, restructuring or similar issues likely to materially affect share prices

In the year 2004 alone the following companies were suspended from trading on the ZSE for one or more of the above reasons: Barbican Bank, CFX Bank, First Mutual Limited, Trust Bank and Trans Zimbabwe Industries (TZI). When you buy shares in a company you own a part of that company and you may benefit by getting part of the profits of that company as dividend payments. Growth in the value of the company is reflected in the value of the shares that you hold.

\section{MATERIALS AND METHODS}

The focus of this review is the determination of stock prices in Zimbabwe. To gather the information that we wanted we used interviews and the archival method. We targeted the people in the various organizations/companies that are registered on the Zimbabwe Stock Exchange, stock exchange staff, stock broking firms, investment analysts. In some instances we engaged people in some informal discussions because if people know that they are being interviewed they tend to withhold some information which they think is sensitive. We also gathered published information ${ }^{[3]}$ from various libraries and the Zimbabwe Stock Exchange publications.

Importance of stock markets: The importance of the stock market as an investment vehicle for the investors is explained here. Very few people in Zimbabwe are aware that they can invest money on the stock market and reap some very lucrative returns through dividends and capital gains. For investors who invest on the market there are of course some risks that they have to live with, for example, the unexpected crashing of the stock market. According to McGregor ${ }^{[6]}$ companies usually borrow money from banks in order to meet their short-term cash requirements. However, when they need long-term finance, they may sell their ownership interests in the company by using common and preferred stocks. Moreover, they can also borrow from the public by selling bonds to meet their long-term capital requirements. Stocks exist to enable companies in need of long-term finance to sell pieces of their business as stocks (equity securities) in exchange for cash. The selling of equity securities is the principal method of raising long-term capital other than the issuing bonds. The publicly held shares can be traded to other investors on the stock market and are in this case, known to be liquid ${ }^{[5]}$. According to Stanlake ${ }^{[7]}$ company shares represent permanent loans and there are no rights to repayment of such loans. He also noted that in the absence of some kind of stock exchange, securities such as these will be very illiquid and it would be very difficult to find buyers for them. Hence, the existence of the stock exchange solves this problem because it provides a market where holders of shares and longterm securities can always buy and sell them.

A company that has obtained permission to have its shares traded on the stock exchange will find it much easier to raise new capital by making an issue of shares. The stock exchange, therefore, is an essential part of the capital market, i.e., market for long-term loans ${ }^{[2]}$.

Shauna Croome ${ }^{[1]}$ states that companies receive money from the securities market only when they first sell a security to the public in the primary market, which is commonly referred to as an Initial Public Offer 
(IPO). It is in the subsequent trading of these shares on the stock market that investors buying and selling the stock would benefit from the movements in the stock price. The benefits accrue through either the appreciation of the stock price or the dividends that are paid out. Croome ${ }^{[1]}$ further went on to explain why management and founder members of a given company care about their stock's performance in the secondary market when the company has already received its money in the IPO. He argued that the explanation lies in the fact that management or founder members of a public company tend to own a significant number of shares and also that salary incentives or stock options for management could be tied to the performance of the company's stock. For these two reasons, management acts as shareholders and thus pay attention to their stock price.

According to McGregor ${ }^{[6]}$ another main role of the stock market is to act as a barometer of the financial health for the companies that are listed. Thus creditors tend to favorably consider companies whose shares are performing very well for financing purposes. This preferential treatment is due to the relationship, which exists between a company's earnings and its share price. Over the long term, strong earnings are a good indication that the company will be able to meet its debt requirements. As a result, the company will receive cheap finance because of the lower risk associated with it.

The Zimbabwe Stock Exchange provides the platform and the means for raising capital for both Zimbabwean and international companies through the issuance of equity, debentures and depository receipts. It also provides investors with the opportunity to buy and sell shares in any company listed on the stock exchange.

The other fact that has to be considered is that a stock exchange has been perceived as the backbone for most contemporary economies, serving a critical need of raising capital funds for companies at a reasonably low cost as compared to other sources of finance such as borrowing ${ }^{[2]}$.

\section{RESULTS AND DISCUSSION}

The determinants of stock prices that we established after analyzing the data that we collected through archival techniques and interviews are summarized below:

Corporate earnings: Information on a company's performance and growth prospects is very important in determining a company's share price. Demand increases for the shares that have a high prospect for growth (blue chip shares). The prices of such shares rise much faster than those of companies whose growth prospects are bleak. The expected receipt of dividend income is sometimes an incentive for investing in a given stock, particularly if the yield on the investment exceeds the return offered on other alternative investments like savings accounts. Investors may pay a premium for shares in issue. The less liquid the shares are, the more difficult they are to come across and one may have to pay a premium in order to get them.

Management: The strength of the management team plays a very crucial role in determining the price of a share. Changes in the management team affect both the risk and returns associated with the counter. If the incumbent management team is perceived to be strong due to its past performance, changes in such a team can result in the dropping of share price and vice versa. The sudden drop in the share price of National Merchant Bank of Zimbabwe (NMBZ) in March 2004 was a result of the fleeing of senior managers of the bank out of the country after it had been discovered that they had committed fraud.

Lawsuits: News of lawsuits against a company can severely affect its share price. Besides the issue of unwanted bad publicity, lawsuits can result in fines, damages and/or withdrawal of trading licenses. This is risky for an investor and therefore causes a plunge in the share price.

Mergers and takeovers: Mergers and takeovers can also affect share prices depending on the market's perception of the merits and demerits of a takeover. For example the share price of Century Bank was negatively affected by its involvement in the ENG saga. However, the news of its proposed merger with CFX Bank helped to strengthen the price of its share even before the merger took place. This is because a strong merger partnership brings shareholder value and reduces risk. De-mergers result in companies unbundling part of their operations (e.g., properties) so as to focus on core business and hence add shareholder value. A good example in Zimbabwe is Zimbabwe Sun group of companies. The share price of Zimbabwe Sun increased from \$20.00- \$180.00 ahead of the group's unbundling of the properties (hotels) in October 2001 to concentrate on the actual provision of the tourism and hospitality services. This resulted in the birth of Dawn properties, which was subsequently listed on the ZSE. 
Market liquidity and stability: When the market is less liquid, there are no funds to buy shares and hence share prices go down especially when supply is high. During financial crises, stock market information is very sensitive and hence share prices are volatile. Stock prices normally decline during the subscription period and when companies announce rights issues.

Stock markets include laws that govern insider trading because this can also lead to share price volatility. Insider dealing is trading of stocks by people within the company who have important information about the direction the company is taking. The public may deduce that when the insiders are buying or selling shares of their own companies, they have some important information about the companies that drive them to do so.

Availability of substitutes: When the market has substitute securities such as loan stocks, unit trusts and treasury bills, the share prices often go down or remain constant. For eight days from the 7th to the 14th of October 2004, most share prices for companies on the ZSE traded at constant prices due to the short term treasury bills that were issued by the central bank during the same period to reduce market liquidity. For example, Old Mutual shares traded at a constant price of $\$ 11800$ during that period even after the publication of some impressive results.

Government policy: Changes or proposed changes in the system of taxation, government spending, monetary policy and in industrial policy (e.g., privatization) can have an important effect on people's willingness to buy or sell shares. In Zimbabwe the recent problems that were experienced in the financial services sector have had profound effect on the financial counters. According to the Business Herald (5th of October 2004) financial counters are no longer as attractive to the prospective investors as they were in the previous years. Sentiments on the financial counters, with the exception of those that are financially stable reached their lowest ebb in 2004. During the first half of the year financial counters either remained static or plummeted, with at least three firms being suspended from trading on the Zimbabwe Stock Exchange. It can also be noted that each time a monetary policy or a government budget statement is presented the share prices are affected in some way. This clearly demonstrates the fact that government policy and actions impact on the share prices of listed companies.
Macroeconomic fundamentals: Interest rates and inflation also have an effect on share prices. Where real interest rates are negative, investors tend to seek alternatives that yield positive returns and shares are one such alternative. As investors move from the money market to the ZSE, share prices are likely to increase due to increased demand. When investors are assured of positive real interest rates on the money market they are more likely to invest on the money market where returns are guaranteed instead of the stock market where returns are uncertain.

The exchange rate also has an effect on share prices as it affects the companies that either export or import. Devaluation of a currency might have a positive effect on the share price of an exporting company as it improves its competitiveness on international market. However, the companies that import raw materials are negatively affected by devaluation as their production costs automatically go up. On the other hand, companies that produce import substitutes are likely to benefit from devaluation as the imported products become less competitive as compared locally produced goods.

Investor sentiments: Share price movements are also explained by the perceptions of the investors. For example in a bull market share prices are expected to rise and in a bear market they are expected to fall. Investor sentiments may be demonstrated through the seasonality of stock markets. For instance, share prices are usually anticipated to fall during the festive season. This compels some investors to redeem their shares just before the beginning of the festive season so as not to experience capital losses.

The level of confidence of the investors in the general economy and economic policies of the country also impact on the share prices. For example, the land reform program, social unrest and policy reversals that were experienced between 1997 and 2001 negatively affected the stock market, as investors were uncertain about the direction the economy was taking. Uncertainties of this nature may also affect the global markets, for example, just after the 11th of September 2001 attack on the USA major world stock markets recorded their lowest volumes of trade.

Technical influences: Technical influences are another factor that impact on share prices. A good example is the ranking of counters according to the performance and the profitability of the companies. Investors tend to regard highly counters in the 'top ten' and these are the companies they would be inclined to invest in. This is a 
self-fulfilling prophecy because as investors demand such shares their prices continue to go up. For example, in Zimbabwe counters such as Old Mutual, Pretoria Portland Cement, British American Tobacco, Delta and Meikles are some of the counters in the top ten and they are the ones that are popular with investors.

Another technical influence is the use of past share prices to forecast how share prices and stock markets will perform in the future. A company's previous performance may always act as a pointer to its future performance and this guides investors as far as their investment decisions are concerned.

Analyst reports: Analysts' recommendations on "buy" or "sell" decisions affect prices of stocks in question as investors normally take heed of such recommendations. The public normally accepts the advice given by the analysts since the analysts are specialists in their respective fields.

\section{CONCLUSION}

The main thrust of the review was to establish the major determinants of stock prices in Zimbabwe. This review also highlighted the history and the importance of the ZSE. We established in our discussions that there are economic, political and social factors that determine stock prices in Zimbabwe. However, economic and political factors seem to be the dominant factors in the determination of stock prices. It can therefore be concluded that if the stock exchange is to perform well the economic and political situation in the country has to be stable. In other words government has to take some deliberate steps to ensure that the economy of the country is well run and also that there is stability politically. During the time this review was conducted there were some political tensions in the country, especially emanating from the redistribution of land to the black Zimbabweans who were marginalized by previous racist colonial governments.

\section{REFERENCES}

1. Shauna, C., 2003. Why do companies care about their stock prices?

http://www.investopedia.com/articles/basics/03/02 0703.asp

2. Kelly, M.V., 1997. Financial Institutions in South Africa: Financial Investment and Risk Management. Juta and Co, Ltd., Cape Town, ISBN: 0702127701, pp: 573.

3. Kolb, R.W., 1996. Financial Management. Blackwell Publishers, Cambridge, UK. ISBN: 1843342286.

4. Lakonishok, J. and R. Smidt, 1998. Are seasonal anomalies real?. A ninety-year perspective- review of financial studies.

http://ideas.repec.org/a/oup/rfinst/v1y1988i4p403425.html

5. Mayer, T., J.S. Duesenberry and R.Z. Aliber, 1996. Money Banking and the Economy. WW Norton and Company, New York, London, ISBN: 0393968480, pp: 594.

6. McGregor, R., 1989. The Mechanics of the Johannesburg Stock Exchange. Juta and Co, Ltd., Cape Town, ISBN: 0-7021-2248-3.

7. Stanlake, G.F., 1993. Introductory Economics. Longman House, Essex, ISBN: 0582354846, pp: 222.

8. Zimbabwe Stock Exchange, 1999. The Investors and Financial Markets Handbook. http://books.google.com.pk/books?id=euSpNwAA CAAJ\&dq=The+investors $\% \mathrm{E} 2 \% 80 \% 99+$ and+Fina ncial+Markets+Handbook

9. Van Horne, J.C., 1998. Financial Management, Prentice Hall Upper Saddle River, New Jersey, USA., ISBN: 0070580413, pp: 360. 